\title{
Penyuluhan Standar Produksi Ayam Petelur Jantan pada Kelompok Ternak Nawawi Farm
}

\author{
Mira Andriani ${ }^{1 *}$, Reikha Rahmasari ${ }^{2}$, Shokhirul $\mathrm{Imam}^{3}$, Niati Ningsih ${ }^{4}$, Aryanti Candra Dewi ${ }^{5}$ \\ 1,2,3,4,5 Jurusan Manajemen Bisnis Unggas, Peternakan, Politeknik Negeri Jember \\ 1*andriani@polije.ac.id, ${ }^{2}$ reikha.rahma19@gmail.com, ${ }^{3}$ shokhirul_imam@polije.ac.id, ${ }^{4}$ niatiningsih@polije.ac.id, \\ 5 aryanticandradewi@polije.ac.id
}

\begin{abstract}
One of the livestock groups engaged in raising male laying hens is the "Nawawi Farm" Farmer Group, which is located in Nogosari Village, Jember Regency. This group is chaired by Mr. Ainul and consists of approximately 100 breeders. Based on discussions with members of the livestock group, breeders have several problems. Farmers experience a lack of standard information on feed nutrient requirements, feed amount and feed conversion. The unknown standard of feed nutrient in male layer hens causes breeders to find it difficult to achieve the target harvest. Therefore, it is necessary to provide counseling on the production standards of male layer hens in the "Nawawi Farm" livestock group. The method of implementing the activity is in the form of a Focus Group Discussion (FGD) with stages, namely the analysis of community needs, counseling on the production standards of male laying hens, and guiding the maintenance of male laying hens. The output of this dedication is that all breeders of the "Nawawi Farm" livestock group can understand the production standards of male laying hens. Rations with protein, namely $18 \%$ crude protein, had no effect on feed consumption, FCR, mortality, production index. Rations with $18 \%$ crude protein can replace rations with $21 \%$ crude protein for feeding male layer hens. This service activity was welcomed by all breeders from the "Nawawi Farm" livestock group so that the service that has been carried out is well organized. Suggestions from this activity are expected that this service will be held at the next meeting in the form of competency training for making rations with the use of local materials in meeting the nutrient feed standards in raising male layer chickens in the "Nawawi Farm" livestock group of Jember Regency, in order to increase the production standards of male layer chickens so that they get greater profit.
\end{abstract}

Keywords: Standard, Production, Male Layer Chicken, Feed, Nawawi Farm

\begin{abstract}
Abstrak
Salah satu kelompok ternak yang bergerak dibidang pemeliharaan ayam petelur jantan adalah Kelompok Peternak "Nawawi Farm" yang berlokasi di Desa Nogosari, Kabupaten Jember. Kelompok ini diketuai oleh Bapak Ainul dan beranggotakan lebih kurang 100 orang peternak. Berdasarkan diskusi dengan anggota kelompok ternak, para peternak memiliki beberapa permasalahan. Peternak mengalami kekurangan informasi standar kebutuhan nutrien pakan, jumlah pakan serta konversi pakan. Belum diketahuinya standar nutrient pakan pada ayam petelur jantan menyebabkan peternak merasa kesulitan dalam mencapai target panen. Oleh karena itu, perlu dilakukan penyuluhan standar produksi ayam petelur jantan pada kelompok ternak "Nawawi Farm". Metode pelaksanaan kegiatan dalam bentuk Focus Group Discussion (FGD) dengan tahapan yaitu analisis kebutuhan masayarakat, penyuluhan standar produksi ayam petelur jantan, dan pembimbingan pemeliharaan ayam petelur jantan. Luaran dari pelaksanan pengabdian yang dilakukan yaitu seluruh peternak kelompok ternak "Nawawi Farm" dapat memahami standar produksi ayam petelur jantan. Ransum dengan protein yaitu protein kasar 18\% tidak berpengaruh terhadap konsumsi pakan, FCR, mortalitas, indeks produksi. Ransum dengan protein kasar $18 \%$ bisa mengantikan ransum dengan protein protein kasar $21 \%$ untuk pemberian pakan ayam petelur jantan. Kegiatan pengabdian ini disambut dengan baik oleh seluruh peternak dari kelompok ternak
\end{abstract}

http://comdev.pubmedia.id | Indonesian Journal Publisher | http://idpublishing.org

Hal 31 dari 35 


\begin{abstract}
"Nawawi Farm" sehingga pengabdian yang telah dilakukan terselenggara dengan baik. Saran dari kegiatan ini diharapkan pengabdian ini diadakan pada pertemuan berikutnya berupa pelatihan kompetensi pembuatan ransum dengan pemanfaatan bahan lokal dalam memenuhi standar nutrient pakan dalam pemeliharan ayam petelur jantan pada kelompok ternak "Nawawi Farm" Kabupaten Jember, untuk dapat meningkatkan standar produksi ayam petelur jantan sehingga mendapatkan profit yang lebih besar.
\end{abstract}

Kata Kunci: Standar, Produksi, Ayam Petelur Jantan, Pakan, Nawawi Farm

*Penulis Korespondensi : Mira Andriani

\section{PENDAHULUAN}

Ayam pejantan petelur adalah ayam jantan final stock tipe petelur yang dianggap sebagai limbah penetasan karena yang dimanfaatkan adalah ayam betina untuk menghasilkan telur. Ayam ini sangat potensial untuk dipelihara untuk menghasilkan daging yang memiliki cita rasa seperti ayam kampung. Masalah yang dihadapi agribisnis peternakan unggas adalah penyediaan bahan baku pakan industri, di mana sebagian besar bahan baku pakan ternak penting harus diimpor, impor jagung mencapai 45 persen, bungkil kedelai 95 persen, tepung ikan 91 persen, serta tepung tulang dan vitamin/feed additive hampir 100 persen impor. Kondisi yang ada pakan unggas 50 persen komponennya terdiri dari jagung, dalam kurun waktu 5 tahun (2004-2009) mengalami dinamika yang cukup signifikan. Dalam perkembangannya maka impor jagung mencapai puncaknya pada tahun 2006 yaitu sebesar 1,5 juta ton dari kebutuhan 3,7 juta ton [1].

Kondisi ini yang membuat dinamika bisnis perunggasan nasional sensitif terhadap kondisi lingkungan eksternal antara lain harga bahan baku pakan yang sebagian besar masih diimpor sehingga kondisi ini membuat fluktuasi harga DOC (day old chicken) dan harga ayam setiap waktu. Hal ini membuat para peternak skala kecil tidak efisien dalam berproduksi walaupun struktur agribisnis sektor ini sudah terbentuk dengan kuat mulai dari hulu sampai ke hilir.

Pakan merupakan komponen yang sangat berpengaruh terhadap keberhasilan suatu peternakan dan merupakan komponen biaya yang besar. Oleh karena itu, dilakukan manajemen pakan yaitu dengan melihat kualitas dan kuantitas pakan sehingga dapat meningkatkan kecernaan pakan penyerapan zat- zat makanan dan efisiensi harga. Protein merupakan persenyawaan organik yang mengandung unsurunsur karbon, hidrogen, oksigen, dan nitrogen [2].

Protein adalah unsur pokok pembentuk alat tubuh dan jaringan lunak tubuh aneka ternak unggas. Protein diperlukan untuk pertumbuhan, pengelolaan, dan produksi daging serta merupakan bagian enzim dalam tubuh dan antibodi. Standar protein untuk stater adalah 20-22\% [3]. Ayam yang lebih tua membutuhkan protein yang lebih rendah dibandingkan dengan ayam yang muda. Salah satu kelompok ternak yang bergerak dibidang pemeliharaan ayam petelur jantan adalah Kelompok Peternak "Nawawi Farm" yang berlokasi di Desa Nogosari, Kabupaten Jember. Kelompok ini diketuai oleh Bapak Ainul dan beranggotakan lebih kurang 100 orang peternak.

Berdasarkan diskusi dengan anggota kelompok ternak, para peternak memiliki beberapa permasalahan yang umum dihadapi. Peternak menyampaikan bahwa manajemen DOC sangat krusial, masalah brooding dan penggunaan bahan/alat pemanas. Masalah lain adalah peternak mengalami kekurangan informasi standar kebutuhan nutrien pakan, jumlah pakan serta konversi pakan. Belum diketahuinya standar tentang ayam jantan petelur menyebabkan peternak merasa kesulitan dalam mencapai target berat panen sekitar $1 \mathrm{~kg}$. Selain itu, masalah yang dihadapi oleh peternak adalah pemasaran ternak/hasil panen. Permasalahan tersebut perlu mendapat perhatian sehingga perlu dicarikan solusi. Diskusi, pembimbingan dan pelatihan menjadi beberapa solusi yang diberikan.

\section{METODE}

Tahapan pelaksanaan kegiatan FGD dan penyuluhan kelompok peternak "Nawawi Farm" Desa Nogosari adalah sebagai berikut:

\subsection{Analisis kebutuhan masyarakat}

Sebelum melaksanakan kegiatan pengabdian, tim melakukan survei awal pada kelompok ternak untuk mendapatkan informasi mengenai kendala yang dihadapi oleh peternak. Hal tersebut dijadikan dasar untuk menentukan pelatihan apa yang sesuai dengan kebutuhan peternak. Permasalahan yang dihadapi oleh Kelompok Peternak "Nawawi Farm" adalah kurang pahamnya peternak tentang 
standar produksi dalam pemeliharaan ayam petelur jantan, terutama kebutuhan pakan, konversi dan recording (konsumsi pakan, pertambahan bobot badan (PBB) dan standar PBB. Hal tersebut penting untuk dicarikan solusi agar peternak dapat memberikan pakan yang tepat untuk ternaknya dan melakukan pencatatan dengan baik, sehingga diketahui biaya pemeliharaan dan produktivitas ternak yang nantinya dapat dijadikan acuan dalam pengembangan usaha.

\subsection{Penyuluhan "Standar Produksi Ayam Jantan Petelur"}

Kegiatan dimulai dengan pembukaan dan perkenalan tim pengabdian yang kemudian dilanjutkan dengan penyampaian materi penyuluhan. Materi disampaikan dengan menampilkan power point dengan durasi 45 menit. Materi yang disampaikan adalah standar produksi ayam petelur jantan, kebutuhan pakan dan nutrien serta produktivitas ternak. Kegiatan selanjutnya adalah diskusi dengan peternak. Para peternak aktif bertanya mengenai kendala yang dihadapi dan saling memberi masukkan/berbagi pengalaman dan bertukar informasi. Kegiatan sarasehan berlangsung pada pukul $10.00-$ 15.00 WIB dengan jeda waktu istirahat pukul $12.00-13.00$ WIB. Adanya penyampaian materi telebih dahulu dalam penyuluhan ini, peternak memahami bahwa mengetahui standar produksi ayam jantan petelur sangatlah penting sehingga peternak bisa memprediksi profit yang didapatkan.

\subsection{Pembimbingan Manajemen Pakan dalam Pemeliharaan Ayam Petelur Jantan \\ Pembimbingan peternak dari kelompok ternak "Nawawi Farm" dilakukan setelah pemberian materi. Bentuk pembimbingan yang diberikan dengan dilakukannya praktik simulasi dalam menetukan standar produksi ayam petelur jantan selama pemeliharaan sehingga dapat mengetahui profit yang dihasilkan.}

\section{HASIL DAN PEMBAHASAN}

Pengabdian kepada masyarakat dilakukan terlebih dahulu analisis kebutuhan masyarakat peternak dalam bentuk Focus Group Discussion (FGD) pada kelompok ternak "Nawawi Farm" di Desa Nogosari, Kecamatan Rambipuji, Kabupaten Jember. Hasil dari FGD tersebut di interpretasikan dalam bentuk pelatihan dengan judul "Penyuluhan Standar Produksi Ayam Petelur Jantan di Kelompok Ternak Nawawi Farm". Adanya pelatihan ini menjadi solusi dalam penyelesaian masalah Kelompok Peternak "Nawawi Farm" sehingga
Peternak mengetahui standar produksi dalam pemeliharaan ayam petelur jantan sehingga mencapai target profit yang diharapkan.

\subsection{Analisis Kebutuhan Masyarakat}

Analisis kebutuhan masyarakat peternak dilakukan dalam bentuk Focus Group Discussion (FGD) pada kelompok ternak "Nawawi Farm" di Desa Nogosari, Kecamatan Rambipuji, Kabupaten Jember. Hasil dari FGD tersebut, adapun masalah yang dihadapi peternak dalam pemeliharaan ayam petelur jantan adalah belum adanya standar mengenai sistem pemeliharaan ayam petelur jantan sebagai ayam pedaging. Selama ini yang telah tersedia adalah standar produksi dari perusahaan pembibitan ayam petelur betina sebagai ayam petelur. Jika ditelaah dari berbagai sumber, ada beberapa penelitian yang sudah dipublikasi mengkaji tentang produktivitas ayam petelur jantan yang dapat dijadikan referensi.

\subsection{Penyuluhan Standar Produksi Ayam Petelur Jantan}

Saat ini peternak mulai berminat mengusahakan anak jantan ayam petelur yang dulu dibuang untuk dibesarkan sebagai penghasil daging. Minat itu ditunjang dengan harga bibit yang murah, dan pertumbuhannya lumayan cepat. Peletakan dagingnya tipis namun padat, dan peletakan lemaknya sedikit. Ukuran badannya tidak beda dengan ayam kampung (buras), demikian pula mutu dagingnya. Jika pemeliharaan ayam petelur jantan dikelola dengan manajeman yang baik, maka akan dapat menghasilkan keuntungan yang besar.

Belum adanya standar mengenai sistem pemeliharaan ayam petelur jantan sebagai ayam pedaging. Selama ini yang telah tersedia adalah standar produksi dari perusahaan pembibitan ayam petelur betina sebagai ayam petelur. Jika ditelaah dari berbagai sumber, ada beberapa penelitian yang sudah dipublikasi mengkaji tentang produktivitas ayam petelur jantan yang dapat dijadikan referensi [4];[5];[6];[7] sebagai berikut.

Tabel 1. Karakteristik produktivitas ayam petelur jantan

\begin{tabular}{|c|c|c|c|c|}
\hline $\begin{array}{c}\text { Umur } \\
\text { (Minggu) }\end{array}$ & $\begin{array}{c}\text { Konsumsi } \\
\text { g/ekor/ } \\
\text { minggu }\end{array}$ & $\begin{array}{c}\text { PBB/ } \\
\text { BB }\end{array}$ & FCR & $\begin{array}{c}\text { Mortalitas } \\
(\%)\end{array}$ \\
\hline 1 & $61,67^{6}$ & $67,00^{6}$ & $0,94^{6}$ & $0^{6}$ \\
\hline 2 & $123,33^{6}$ & $126,42^{6}$ & $1,49^{6}$ & $0,17^{6}$ \\
\hline 3 & $189,00^{6}$ & $197,84^{6}$ & $1,88^{6}$ & $0,17^{6}$ \\
\hline 4 & $293,00^{6}$ & $275,00^{6}$ & $2,45^{6}$ & $0^{6}$ \\
\hline
\end{tabular}




\begin{tabular}{|c|c|c|c|c|}
\hline 5 & $287,00^{6}$ & $320,60^{6}$ & $3,08^{6}$ & $0^{6}$ \\
\hline 6 & $526,00^{6}$ & $190,10^{4}$ & $3,17^{6}$ & $0^{6,7}$ \\
& & $468,60^{6}$ & & \\
\hline 7 & $231,26^{4 \wedge}$ & $111,93^{4^{\wedge}}$ & - & $0^{6^{\wedge}}$ \\
\hline Rata-rata & $246,66^{6}$ & $242,50^{6}$ & $2,17^{6}$ & $0,06^{6}$ \\
\hline Akhir & $2584,70^{7}$ & $804,50^{5 *} ;$ & $2,07^{4} ;$ & - \\
& & $1187,50^{7}$ & $2,08^{7}$ & \\
\hline
\end{tabular}

Keterangan:

${ }^{[4]}$ Ardiansyah et al. (2013):;5] Setiadi et al. (2013); $;{ }^{[6]}$ Setiyono et al. (2015); ${ }^{[7]}$ Daud et al. (2017);

*lama pemeliharaan 5 minggu; ^lama pemeliharaan 7 minggu; tidak ada *^ lama pemeliharaan 6 minggu

Karakteristik produktivitas ayam petelur jantan yang telah di rekap oleh tim pengabdian dapat dilihat dari Tabel.1. Dari data tersebut tim pengabdian merujuk data dari [6] dengan ransum dengan protein yang berbeda yaitu protein kasar $18 \%$, protein kasar $21 \%$, dan protein kasar $23 \%$ tidak berpengaruh terhadap konsumsi pakan, FCR, mortalitas, indeks produksi. Hal ini memperlihatkan bahwa ransum dengan protein kasar $18 \%$ mampu mempertahankan standar produksi ayam petelur jantan.

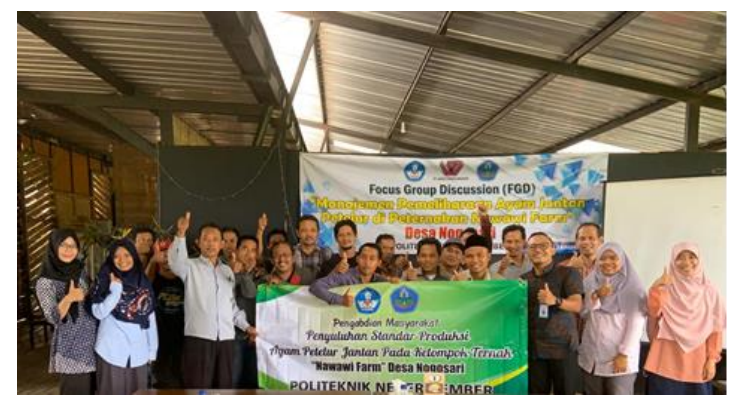

Gambar 1. Kegiatan tim pengabdian bersama kelompok ternak "Nawawi Farm"

Disamping itu juga kegiatan tim pengabdian Bersama kelompok ternak "Nawawi Farm" (dapat dilihat pada Gambar 1.), dengan adanya FGD antara tim pengabdian dan kelompok ternak "Nawawi Farm " dalam menentukan standar produksi yang diharapkan sejalan dengan tercapainya indek produksi. Tim pengabdian menyampaikan faktor yang mempengaruhi nilai indek performa yang maksimal adalah: rata-rata berat ayam saat panen, persentase kematian, rata-rata umur panen, dan Feed Conversion Ratio (FCR). Indek Produksi (IP). Untuk mencari nilai indek produksi dengan rumus:

$\mathrm{IP}=\frac{(100-\% \text { Mortalitas }) \times \text { Bobot Badan rata-rata }}{\text { FCR X Umur rata-rata }} \times 100 \%$
Nilai indek produksi menunjukkan tingkat efisiensi dalam pemeliharaan petelur jantan [8]. Indek Produksi (IP) diartikan baik apabila didukung kematian yang rendah, berat badan yang tinggi, dan efisien dalam penggunaan pakan. Nilai indek produksi akan tinggi apabila didukung dengan faktor genetic yang baik dan kualitas pakan yang baik. Faktor lain yang mempunyai peran penting adalah manajemen pemeliharaan yang baik.

Manajemen pemeliharaan yang diartikan baik apabila dapat meminimalkan kesalahan pada fase pemeliharaan, yaitu fase brooding sampai panen. Pengaruh dari faktor genetik, pakan, dan manajemen yang baik. Tujuan akhir memaksimalkan faktor di atas adalah tercapainya indek produksi (IP) yang tinggi sehingga berpengaruh terhadap biaya pemeliharaan ayam petelur jantan. Nilai IP yang tinggi juga dapat diartikan semakin efisien biaya yang dipakai untuk usaha tersebut [9].

Dalam pemeliharaan ayam petelur jantan untuk memenuhi standar produksinya pemberian standar formulasi pakan perlu di perhitungkan untuk mencapai profit yang lebih besar. Pemberian pakan ayam ada 2 (dua) fase yaitu fase starter (umur 0-4 minggu) dan fase finisher (umur 4-6 minggu) [10].

a. Kualitas dan kuantitas pakan fase starter adalah sebagai berikut:

Kualitas atau kandungan zat gizi pakan terdiri dari protein 22-24\%, lemak 2,5\%, serat kasar 4\%, Kalsium (Ca) 1\%, Phospor (P) 0,7-0,9\%, ME 2800-3500 Kkal. Kuantitas pakan terbagi/digolongkan menjadi 4 (empat) golongan yaitu minggu pertama (umur 1-7 hari) 17 gram/hari/ekor; minggu kedua (umur 8-14 hari) 43 gram/hari/ekor; minggu ke-3 (umur 15-21 hari) 66 gram/hari/ekor dan minggu ke-4 (umur 22-29 hari) 91 gram/hari/ekor. Jadi jumlah pakan yang dibutuhkan tiap ekor sampai umur 4 minggu sebesar 1.520 gram.

b. Kualitas dan kuantitas pakan fase finisher adalah sebagai berikut:

Kualitas atau kandungan zat gizi pakan terdiri dari protein 18,1-21,2\%; lemak 2,5\%; serat kasar 4,5\%; kalsium (Ca) 1\%; Phospor (P) 0,7-0,9\% dan energi (ME) 2900-3400 Kkal. Kuantitas pakan terbagi dalam empat golongan umur yaitu: minggu ke-5 (umur 30-36 hari) 111 gram/hari/ekor; minggu ke-6 (umur 37-43 hari) 129 gram/hari/ekor; minggu ke7 (umur 44-50 hari) 146 gram/hari/ekor dan minggu ke-8 (umur 51-57 hari) 161 gram/hari/ekor.

\subsection{Pembimbingan Manajemen Pakan dalam Pemeliharaan Ayam Petelur Jantan}


Disamping itu dalam pemeliharan hal yang perlu diperhatikan yaitu manajemen pakan yang meliputi;

1) Peralatan.

Kualitas tempat pakan dan air minum mempengaruhi tingkat konsumsi, oleh karena itu peralatan yang digunakan harus terbuat dari bahan yang tidak beracun, warnanya menarik, tahan terhadap panas dan asam, mudah dibersihkan dan tidak mudah pecah.

2) Instalasi tempat pakan dan air minum.

Instalasi tempat pakan dan air minum mempengaruhi tingkat munculnya penyakit dan konsumsi.

3) Kualitas pakan dan air minum.

Kualitas pakan sebelum diberikan harus diketahui secara jelas. Kualitas fisik pakan minimal tidak kadaluarsa, tidak apek, tidak berkutu dan tidak berjamur. Selain kualitas fisik, kualitas kimia juga perlu diketahui, seperti kandungan protein, lemak, abu, serat, $\mathrm{Ca}, \mathrm{P}$, asam amino dan vitamin. Selain itu perlu menerapkan sistem FIFO (First In First Out), yaitu pakan yang pertama masuk dalam gudang maka digunakan yang pertama. Pakan bentuk pellet lebih tahan lama daripada bentuk mess. Pakan pellet bagus digunakan $<30$ hari setelah diproduksi, lebih dari itu cenderung akan mengalami kerusakan.

4) Teknik pemberian pakan dan air minum.

Teknik pemberian yang tepat akan memberikan tingkat efisiensi pakan, yaitu pakan habis tanpa ada yang tercecer. Sehingga secara tidak langsung biaya pakan dapat ditekan.

Strategi yang dilakukan adalah memperhatikan waktu, frekuensi, jumlah pemberian, kondisi tempat pakan dan tempat minum, serta kondisi lingkungan. Secara alamiah ayam makan sebelum matahari terbenam dan sebelum matahari terbit. Oleh karena itu porsi pemberian pakan hendaknya dilebihkan pada waktu tersebut (pagi $\pm 30-40 \%$, malam $\pm 60-70 \%$ ). Kondisi lingkungan yang panas akan mengurangi konsumsi pakan, sehingga pada siang hari kegiatan pemberian pakan tidak dilakukan atau dipuasakan.

\section{KESIMPULAN}

Ransum dengan protein kasar $18 \%$ untuk pemberian pakan ayam petelur jantan mampu mempertahankan standar produksi ayam jantan petelur. Kegiatan pengabdian ini disambut dengan baik oleh seluruh peternak dari kelompok ternak "Nawawi Farm" sehingga pengabdian yang telah dilakukan terselenggara dengan baik. Saran dari kegiatan ini diharapkan pengabdian ini diadakan pada pertemuan berikutnya berupa pelatihan kompetensi pembuatan ransum dengan pemanfaatan bahan lokal dalam memenuhi standar nutrient pakan dalam pemeliharan ayam petelur jantan pada kelompok ternak "Nawawi Farm" Kabupaten Jember, untuk dapat meningkatkan standar produksi ayam petelur jantan sehingga mendapatkan profit yang lebih besar.

\section{UCAPAN TERIMAKASIH}

Tim pengabdian mengucapkan terimakasih kepada kelompok ternak "Nawawi farm", atas waktu dan kesediaan pada kegiatan pengabdian ini.

\section{DAFTAR PUSTAKA}

[1] [DITJENNAK] Direktorat Jenderal Peternakan. 2010. Pedoman Umum Restrukturisasi Perunggasan melalui Pengembangan Budidaya Unggas Di Pedesaan (Village Poultry Farming). Jakarta: Direktorat Jenderal Peternakan.

[2] Anggorodi R. 1985. Kemajuan mutakhir dalam ilmu makanan ternak unggas. Gramedia, Jakarta.

[3] Rasyaf M. 2000. Manjemen peternakan ayam broiler. Penebar Swadaya, Jakarta.

[4] Ardiansyah F., S. Tantalo, dan K. Nova. 2013. Perbandingan performa dua strain ayam jantan tipe medium yang diberi ransum komersial broiler. J. Ilmiah Pet. Terpadu. Vol. 1 (2).

[5] Setiyono E, D Sudrajat, dan Anggraeni. 2015. Penggunaan kadar protein ransum yang berbeda terhadap performa ayam jantan petelur. Jurnal Pertanian 6(2): 68-74.

[6] Setiyono E., D. Sudrajat, dan Anggraeni. 2015. Penggunaan kadar protein ransum yang berbeda terhadap performa ayam jantan petelur. J. Pertanian. Vol. 6 (2): 68-74.

[7] Daud M., Z. Fuadi dan Mulyadi. 2017. Performa dan persentase karkas ayam ras petelur jantan pada kepadatan kandang yang berbeda. Agripet. Vol. 17 (1): 67-74.

[8] Pokphand C. 2005. Charoen Pokphand broiler breeder guide principles. Charoen Pokphand.

[9] Fadilah R. 2004. Ayam broiler komersil. Cetakan ke-2. Agromedia Pustaka, Jakarta.

[10] http://cybex.pertanian.go.id/mobile/artikel/90217/PEMELIHA RAAN-AYAM-RAS-PETELUR/ 